\title{
NOTE
}

\section{Oxygen consumption and temperature change in the shrimp Palaemon elegans}

\author{
J. Dalla Via
}

Institut für Zoologie, Abteilung Zoophysiologie, Peter-Mayr-Straße 1a, A-6020 Innsbruck, Austria

\begin{abstract}
Oxygen consumption responses to short-term temperature changes were measured in a Mediterranean population of the shrimp Palaemon elegans (Rathke). At all temperatures between 5 and $25^{\circ} \mathrm{C}$ small shrimp with a body weight of $150 \mathrm{mg}$ showed higher rates of oxygen consumption than larger shrimp. Handling affects metabolic rate; the latter stabilizes only after more than $10 \mathrm{~h}$, especially in small shrimp. $\mathrm{Q}_{10}$-values decrease with decreasing shrimp weight and with rising temperature. Compared to a cold-acclimated population of the same species (Alcaraz 1974) metabolic rates at 15 and $20^{\circ} \mathrm{C}$ are lower in the warm-acclimated Mediterranean population used in this investigation.
\end{abstract}

\section{INTRODUCTION}

The crustacean Palaemon elegans inhabits rock pools in the intertidal zone where it is frequently exposed to high temperatures (Höglund 1943, Forster 1951, Morris \& Taylor 1983). It also populates shallow sand bottoms and brown algae belts. In the latter this shrimp normally competes with Palaemon serratus (Berglund 1980, 1982, 1984, Berglund \& Bengtsson 1981). In the Mediterranean, $P$. elegans is found along rocky coasts (Manning \& Śtevčić 1982) but it also migrates into the shallow water of lagoons (Pellizzato et al. 1981, Crivelli 1982, Manning and Froglia 1982, Türkay 1982, Dalla Via 1983a). There the shrimp are exposed to marked diurnal and seasonal temperature changes. In the Lagoon of Lesina, $P$. elegans is exposed to yearly temperature fluctuations between 5 and $31^{\circ} \mathrm{C}$ (Marolla 1980). Daily fluctuations from 24 to $30^{\circ} \mathrm{C}$ or from 16 to $23^{\circ} \mathrm{C}$ within the same month are not infrequent (June; Lumare 1984). The aim of this study is to consider the effects of short-term changes in environmental temperature on the rate of oxygen consumption of this species.

\section{MATERIALS AND METHODS}

Animals. Shrimp were obtained from the Lagoon of Lesina (southern Italy) where they occur near the open- ings to the Adriatic Sea in salinities ranging from 25 to $40 \%$. The Lagoon of Lesina is a brackish-water lagoon; its dynamics and physico-chemical parameters have been described by De Angelis (1953, 1963). Marolla (1980), Dalla Via (1983a). During the period of investigation the environmental temperature fluctuated between 18 and $22^{\circ} \mathrm{C}$. The shrimp were caught in the Lagoon and transported to the laboratory in original sea water. They were maintained at a constant temperature of $20^{\circ} \mathrm{C}$ in an acclimation chamber for $2 \mathrm{~d}$ before being used for determination of oxygen consumption. Experiments were carried out at the Laboratory for the Biological Exploitation of the Lagoons, Lesina, Italy.

Respirometry. Oxygen consumption measurements were made with an automated multiple-chamber intermittent-flow respirometer (Forstner 1983a, b, Dalla Via 1985b). Since crowding affects the rate of oxygen consumption in other palaemonids (Dalla Via 1985a,b), the 8 shrimp per experimental chamber were separated from each other by a stainless-steel net cage. Bacterial respiration was taken into account by subtraction, as described by Dalla Via (1983b). Four experiments were carried out with the following weight classes: $150 \pm 38 \mathrm{mg}, 275 \pm 72 \mathrm{mg}, 481 \pm 133 \mathrm{mg}$, $998 \pm 40 \mathrm{mg}$.

\section{RESULTS AND DISCUSSION}

Effects of acute change in experimental temperature on the metabolic rate of shrimp acclimated to an environmental temperature of $20^{\circ} \mathrm{C}$ are shown in Fig. 1. At all temperatures small shrimp with a body weight of $150 \mathrm{mg}$ exhibited higher rates of oxygen consumption than larger ones (Fig. 2). Between 5 and $15^{\circ} \mathrm{C}$ the $\mathrm{Q}_{10}$-values lie between 3 and 4 ; they decrease with a rise in temperature (Table 1). Similar $\mathrm{Q}_{10^{-}}$-values have been reported for $20^{\circ} \mathrm{C}$ acclimated Palaemonetes antennarius (Dalla Via 1985b), whereas $P$. vulgaris has lower values (McFarland \& Pickens 1965). Table 1 also 


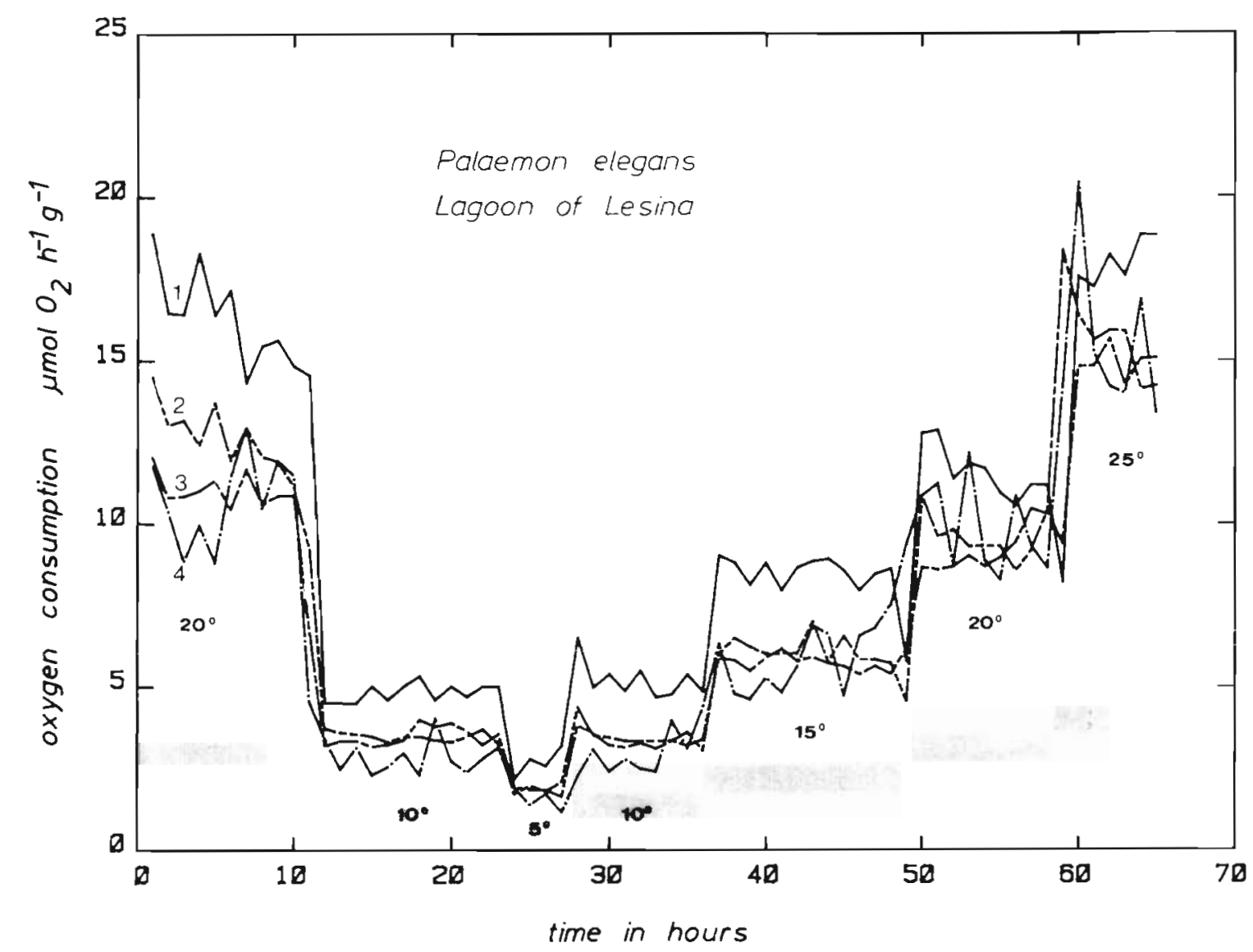

Fig. 1. Palaemon elegans. Time course of oxygen consumption at different temperature levels, indicated by shaded bars at the bottom of the figure. Mean shrimp weight in $\mathrm{mg}$ : Curve $1,150 \pm 38 ; 2,275 \pm 72 ; 3,481 \pm 133 ; 4,998 \pm 40$

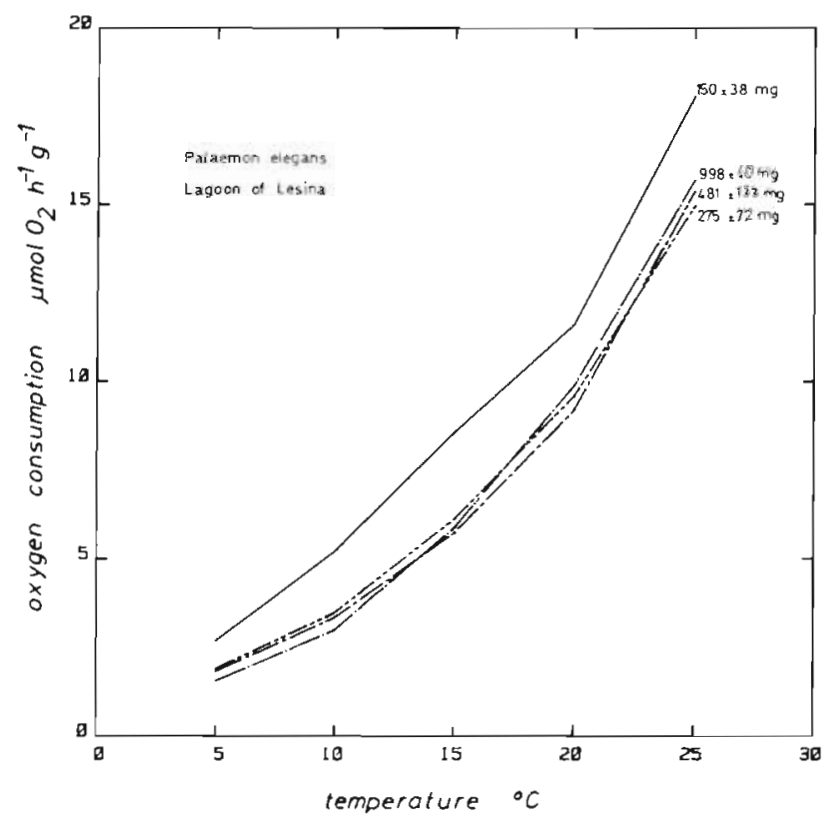

Fig. 2. Palaemon elegans. Effect of temperature on weightspecific oxygen consumption. Fresh body weights indicated $($ mean $\pm \mathrm{SD})$ indicates that large shrimp with a body weight of $1 \mathrm{~g}$ generally exhibit higher $Q_{10}$-values than small shrimp. In a cold-acclimated population of Palaemon elegans a constant $\mathrm{Q}_{10^{-}}$-value (15 to $20^{\circ} \mathrm{C}$ ) of 2.2 was found in individuals of all sizes tested (Alcaraz 1974). When comparing the rates of the cold-acclimated with those of the warm-acclimated populations (Table 2) the effect of handling must be taken into account. From Fig. 1 it is evident that at $20^{\circ} \mathrm{C} \mathrm{P}$. elegans exhibits an initially increased level of oxygen consumption which stabilizes only after more than $10 \mathrm{~h}$. This is especially true for small shrimp. Dalley \& Bailey (1981) also found increased locomotory activity in $P$. elegans for up to $8 \mathrm{~h}$

Table 1 Palaemon elegans. Size dependence of the $Q_{10^{-}}$ values at 3 different temperature intervals

\begin{tabular}{|lcccc|}
\hline $\begin{array}{l}\text { Temperature } \\
\text { interval }\end{array}$ & 150 & 275 & 481 & 998 \\
\hline $5-15^{\circ} \mathrm{C}$ & 3.19 & 3.22 & 3.14 & 3.78 \\
$10-20^{\circ} \mathrm{C}$ & 2.22 & 2.75 & 2.75 & 2.30 \\
$15-25^{\circ} \mathrm{C}$ & 2.11 & 2.44 & 2.68 & 2.67 \\
\hline
\end{tabular}


Table 2. Palaemon elegans. Rates of oxygen consumption of a warm-acclimated and a cold-acclimated population. Values from literature converted to $\mu \mathrm{mol} \mathrm{O}_{2} \mathrm{~g}^{-1} \mathrm{~h}^{-1}$; $\mathrm{n}$-values for $\dot{\mathrm{V}}_{\mathrm{O}_{2}}$ in this study represent $\mathrm{n}$ hourly measurements of a pool of 8 shrimp

\begin{tabular}{|c|c|c|}
\hline & Alcaraz (1974) & This study \\
\hline Time after handling: & $1-2 \mathrm{~h}$ & $10 \mathrm{~h}$ \\
\hline Acclimation temperature: & $12^{\circ} \mathrm{C}$ & $20^{\circ} \mathrm{C}$ \\
\hline \multicolumn{3}{|l|}{ Small shrimp } \\
\hline Weight range in $\mathrm{mg}$ : & $80-260(6)$ & $150 \pm 38(8)$ \\
\hline $\mathrm{V}_{\mathrm{O}}$ in $\mu \mathrm{mol} \mathrm{O} \mathrm{O}_{2} \mathrm{~g}^{-1} \mathrm{~h}^{-1}$ at $15^{\circ} \mathrm{C}$ & $15.4 \pm 2.7(3)$ & $8.6 \pm 0.4(12)$ \\
\hline$\dot{\mathrm{V}}_{2}$ in $\mu \mathrm{mol} \mathrm{O}_{2} \mathrm{~g}^{-1} \mathrm{~h}^{-1}$ at $20^{\circ} \mathrm{C}$ & $23.8 \pm 6.4(3)$ & $11.6 \pm 0.8(9)$ \\
\hline \multicolumn{3}{|l|}{ Large shrimp } \\
\hline Weight range in $\mathrm{mg}$ : & $1090-1140(2)$ & $998 \pm 40$ \\
\hline$\dot{\mathrm{O}}_{2}$ in $\mu \mathrm{mol} \mathrm{O} \mathrm{O}_{2} \mathrm{~g}^{-1} \mathrm{~h}^{-1}$ at $15^{\circ} \mathrm{C}$ & $10.3(1)$ & $5.9 \pm 1.0(12)$ \\
\hline$\dot{\mathrm{V}}_{\mathrm{O}_{2}}$ in $\mu \mathrm{mol} \mathrm{O} \mathrm{O}_{2} \mathrm{~g}^{-1} \mathrm{~h}^{-1}$ at $20^{\circ} \mathrm{C}$ & $10.1(1)$ & $9.9 \pm 1.4(9)$ \\
\hline
\end{tabular}

after placing them in the actograph, and in connection with light on/light off signals. We believe the oxygen consumption levels determined by Alcaraz (1974) must include a high activity component because his measurements were carried out within the first or second hour after handling.

Acknowledgements. I am grateful to Professor W. Wieser for critical reading of the manuscript and to Professor F. Lumare for his kind hospitality at the Laboratory for the Biological Exploitation of the Lagoons, National Research Council, Lesina, Italy. The study was supported by project no. 3307 of the 'Fonds zur Förderung der wissenschaftlichen Forschung in Ósterreich'.

\section{LTTERATURE CITED}

Alcaraz, M. (1974). Consumo de oxígeno en función del tamano y la temperatura en crustáceos. Investigación pesq. 38 (2): $289-304$

Berglund, A. (1980). Niche differentiation between two littoral prawns in Gullmar Fjord. Sweden: Palaemon adspersus and P. squilla. Holarct. Ecol. 3: 111-115

Berglund, A. (1982). Coexistence, size overlap and population regulation in tidal vs. non-tidal Palaemon prawns. Oecologia (Berl.) 54: 1-7

Berglund, A. (1984). Reproductive adaptations in two Palaemon prawn species with differing habitat requirements. Mar. Ecol. Prog. Ser. 17: 77-83

Berglund, A., Bengtsson, J. (1981). Biotic and abiotic factors determining the distribution of two prawn species: Palaemon adspersus and Palaemon squilla. Oecologia (Berl.) 49: 300-304

Crivelli, A. J. (1982). Biology of three Malacostraca (Decapoda) in a Mediterranean lagoon with particular emphasis on the effect of rapid environmental changes on the activity (catchability) of the species. Estuar. coast. Shelf Sci. 15: 591-604

Dalla Via, G. J. (1983a). Ecological studies on the freshwater shrimp Palaemonetes antennarius of Laguna di Lesina (Gargano, South Italy). Arch. Hydrobiol. 97 (2): 227-239

Dalla Via, G. J. (1983b). Bacterial growth and antibiotics in animal respirometry. In: Gnaiger, E., Forstner, H. (ed.)
Polarographic oxygen sensors, aquatic and physiological applications. Springer-Verlag, Berlin, Heidelberg, New York, p. 202-218

Dalla Via, G. J. (1985a). Salinity response of the juvenile penaeid shrimp Penaeus japonicus. I. Oxygen consumption and estimations of productivity. Aquaculture (in press)

Dalla Via, G. J. (1985b). Salinity and temperature responses in a fresh and brackish water population of Palaemonetes antennarius. I. Oxygen consumption. Comp. Biochem. Physiol. (in press)

Dalley, R., Bailey, H. (1981). A new apparatus used to record the locomotor rhythms of laboratory reared prawns and shrimps. Mar. Ecol. Prog. Ser. 4: 229-234

De Angelis, C. M. (1963). Notizie fisico-chimiche e biologiche sui Laghi di Lesina e Varano. Boll. Pesca Piscicoltura Idrobiol. 18: 107-124

De Angelis, R. (1953). Il Lago di Lesina. Ministero della Marina Mercantile, Memoria No. 9: 1-110

Forster, G. R. (1951). Notes on Leander squilla L. J. mar. biol. Ass. U.K. 30: 333-360

Forstner, H. (1983a). An automated Multiple-Chamber Intermittent-Flow Respirometer. In: Gnaiger, E., Forstner, H. (ed.) Polarographic oxygen sensors, aquatic and physiological applications. Springer-Verlag, Berlin, Heidelberg, New York, p. 111-126

Forstner, H. (1983b). Electronic circuits for polarographic oxygen sensors. In: Gnaiger, E., Forstner, H. (ed.) Polarographic oxygen sensors, aquatic and physiological applications. Springer-Verlag, Berlin, Heidelberg, New York, p. $90-101$

Höglund, H. (1943). On the biology and larval development of Leander squilla L. forma typica de Man. Svenska Hydrografisk-Biologiska Kommissiones skr. Stockholm N.S. 2: $1-44$

Lumare, F. (1984). Stocking trials of Penaeus japonicus Bate (Decapoda, Natantia) postlarvae in Lesina Lagoon (Southeast coast of Italy). In: Management of Caastal Lagoon Fisheries, FAO Studies and Reviews No. 61, Vol. 2: 593-606

Manning, R. B., Froglia, C. (1982). On a collection of decapod crustacea from southern Sardinia. Quaderni del Laboratorio di Tecnologia della Pesca, Ancona, Consiglio Nazionale delle Ricerche 3 (2-5): 319-334

Manning, R. B., Stevčić, Z. (1982). Decapod fauna of the Piran gulf. Quaderni del Laboratorio di Tecnologia della Pesca, 
Ancona, Consiglio Nazionale delle Ricerche 3(2-5): 285-304

Marolla, V. (1980). Nota preliminare su alcune caratteristiche chimico-fisiche della Laguna di Lesina nel biennio 1970-71. Istituto per lo Sfruttamento Biologico delle Lagune, Lesina, Consiglio Nazionale delle Ricerche, Rapporto No. 3: 1-23

McFarland, W N., Pickens, P. E. (1965) The effect of season, temperature, and salinity on standard and active oxygen consumption of the grass shrimp, Palaemonetes vulgaris (Say). Can. J. Zool. 43: 571-585

Morris, S., Taylor, A. C. (1983). Diurnal and seasonal variation in physico-chemical conditions within intertidal rock pools. Estuar. coast. Shelf Sci. 17: 339-355

Pellizzato, M., Favretti, G., Dal Compare, G. (1981). Nuove osservazioni sulla macrofauna attratta da esche di pesci morti nella Laguna di Venezia. Lavori - Societá Veneziana di Scienze Naturali 6: 113-118

Türkay, M. (1982). Results of collecting Decapods with small traps in the Aegean sea. Quaderni del Laboratorio di Tecnologia della Pesca, Ancona, Consiglio Nazionale delle Ricerche 3 (2-5): 339-345

Accepted for printing on July 14, 1985 